\title{
Fantasies of Contact in a Transnational Frame: A Transactional Reading
}

\author{
Julia Emberley
}

\section{Fantasmagories du contact dans un cadre transnational: Une lecture transactionnelle}

La fourrure est une matière première fétichisée qui peut être le symbole de la santé et qui donne un certain statut au propriétaire, c'est un objet qui était primordial dans les rapports initiaux entre l'Europe occidentale et l'Amérique du Nord et qui est aujourd'hui un symbole politique pour les activistes écologiques. La symbolique de la fourrure est revisitée à travers une série de textes dans cet essai de Julia Emberley. Du film Sammy and Rosie Get Laid, à certaines histoires de Audre Lorde et Franz Kafka, en passant par une annonce de Diesel, l'auteure veut faire la démonstration que ce qui semble être la signification naturelle d'une chose, comme la fourrure, est en fait le produit de certains sites de signification matérielle, est fabriquée. La lecture que livre Emberley est particulièrement attentive aux «échanges transactifs» spécifiques à ces sites de signification matérielle; "négociant dans le contestable domaine de l'espace décolonisé», elle dévoile la nature fantasmatique de toute tentative d'intégrer la fourrure dans un régime de vérité. L'auteure insiste pour dire que l'imaginaire culturel a des effets réels et montre bien dans la dernière partie de sonessai comment toute une logique raciste est mise en scène par un exercice pédagogique avec lequel on fait éprouver l'expérience de l'oppression. Cette section fait ressortir les contradictions existant entre les féminismes matérialistes et l'ignorance consentie face à l'impérialisme de la culture occidentale, soulignant quel'on doit décoloniser les pratiques de lecture phantasmatiques en continuant de se poser cette question:à qui profite que l'on entretienne l'aveuglement face aux complicités transactionnelles? 
There is interest, often unperceived by us, in not allowing transnational complicities to be perceived. - Gayatri Chakravorty Spivak, Outside in the Teaching Machine

Fantasies of contact are part of the store of origin tales that permeate the history of colonialism. In the imperial imaginary, they live in the domain of the present as perpetual residues of the terror and disturbance of an uncontrollable rupture in the enclosed space of Indian territory: the empire penetrates the intact world of the aboriginal, generates a new world and names it a colony, another word for the empire's Other. From here on, the originary violence of contact is perceived by the empire to have radically altered the geo-political landscape. A new world is born and the old world - the world of the aboriginal, that is - must wither away. So the story goes. Edward S. Curtis, in his well-known late-nineteenth-century photographic simulations, called the effects of this disastrous contact in America a "vanishing race" phenomenon. The origin story represents a fantasy of contact with the 'other,' a momentary projection onto the past in an effort to sustain the radical discontinuities of the present. Yet, while the origin story is a simulation of a desire for domination, its effects are very real.

This essay will elaborate several different kinds of fantasies involved in the 'contacts' brought about by historical and current forces of imperialism. The first three parts address varying incidents in the history of the material culture of fur. Part four is a fantastic rendition of a pedagogical exercise used to teach students about the originary violence of 'contact.' The exercise involves a simulation of an invading imperialist force in "present day" Canada, authorized by the United States, called New Arabia.

First, let me contextualize parts one, two, and three in a transnational frame. The significance of fur lies in the fact that this object played an important role in the initial contact between Western Europe and North America during the early modern period. The fur trade provided a source of mercantile wealth to Britain and France and brought about a new political economy which eventually came to dominate indigenous modes of gatherer/hunter production and consumption. Since the sixteenth century fur has entered a multiplicity of sign systems: as a sexual fetish in the discourses of late nineteenth-century masochism, as a code of wealth and status in the discourses of fashion, and in our current moment as a sign around which to mobilize an ecological activism. 
Perhaps nowhere have the contestatory effects of the political and libidinal economies of fur become more visible than in the context of contemporary political struggles over fur trapping by First Nations and anti-fur animal rights activism. ${ }^{1}$ As the symbolic power invested in fur suggests, fur is not only a commodity or a sexual fetish, it is also a material signifier in the transnational discourses of political and libidinal exchange.

In The German Ideology Marx writes:

The cherry-tree, like almost all fruit-trees, was, as is well known, only a few centuries ago transplanted by commerce into our zone, and therefore only by this action of a definite society in a definite age has it become "sensuous certainty" for Feuerbach. (qtd. in Landry and MacLean 67)

Feuerbach's notion of sensuous certainty, Marx argues, cannot be abstracted from the realm of deterministic limits, a definitiveness of time and place produced by the exchange of wealth and objects. To suggest otherwise is to posit a fetishistic ideal in which a thing exists simply as a thing, endowed with meanings and values that are intrinsic, mythical, and immutable. In the quote above, a demystification of the fetishism of sensuous certainty takes place and the cherry-tree is placed in a field of trans-actions. For Marx, those transactions are largely of a commercial sort where an exchange of economic interests determines the facticity of the cherry-tree's existence in Europe. What we perceive to be nature, and therefore natural, Marx would have us understand as a product of highly mobile circulations and transactive exchanges, be they economic, ecological, libidinal, or discursive. It is in these possible sites of transaction that the cherry-tree constitutes itself as a material signifier. Meanings are attributed to it, such as that of natural object, and values are accrued. Similarly, in the social production of values for fur, textual transactions are taking place in which the signs of fur - expressed succinctly by Gustave Flaubert in The Dictionary of Received Ideas: FUR: Sign of Wealth - figure as tokens of exchange. A transactional reading traces the process of negotiation by which these signs, these tokens, acquire their value(s) and hence achieve a level of material signification. Not only does a transactional reading map the commerce of textual exchange, it also participates in the negotiations, deploying strong and weak forces so as to mobilize such dualities as woman/man and human/animal out of their fetishistic regimes of truth. The gender differences which give relative value to these dualities are then subject to a process of disassemblage 
whereby the edifice of imperial violence (specific to the history of the traffic in furs) that constructs fine distinctions is displaced and the fluidity and permeability of borders set in motion.

By addressing the material significance and significations of fur, I am also interested in pushing through the boundaries of a larger question: the problem of uneven tensions and productive as well as debilitating contradictions that surround the relationship between materialist feminisms, the often sanctioned ignorance of European cultural imperialism and the colonial re-territorialization of the globe. I view this question, not as one that can be easily answered, but as a condition of possibility for an analysis of how those tensions and contradictions shape contemporary political actions and struggles against the intolerable exploitation of women, men, children, animals and the earth.

\section{First Territory}

To the opera on Friday with a vegetarian friend. A woman in a long sablecoat sits next to us. My friend says:IwishIcarried a can of spray paint in my bag and could shoot it over her coat. Thought it might be an idea to stick in the film. But where? - Hanif Kureishi, Sammy and Rosie Get Laid:The Screenplay and the Screenwriter's Diary

Near the conclusion to the film Sammy and Rosie Get Laid, when the exodus of caravans from the waste ground takes place due to property development, the property developer's wife stands on the periphery observing the scene in her long sable coat. Rani crosses behind her and spray-paints an " $X$ " on her back. (See 54-55 of the text.) This is a politically correct gesture, an act of desecration of a bourgeois fetish legitimated by the emergence of a strong anti-fur trapping/fur factory movement in Britain in the 1980s. However, even this progressive act of protest bears the contradictions of its class affiliations, foregrounded no less by the fact that the idea to include this singular gesture in the film emerges for Kureishi at the opera.

The contradictions of class inhere among and within the new social movements, including feminism, the Green movement, Lesbian and Gay, anti-racist, and anti-imperialist struggles. Social antagonism (the contradictions and tensions constitutive to class relations) represents the mode of affiliation that articulates - whether in complicity or solidarity - relations of struggle. Sammy and Rosie Get Laid is the kind of extra- 
ordinary film for which the complex and fragmentary assortment of characters, images, and narratives makes it possible to read many lines of cultural and political critique. This multi-critique the film engenders represents its own kind of resolution to the contradictions of material life. Gayatri Chakravorty Spivak addresses a fragment of this multidimensional field in which British feminism confronts the history of British imperialism. In her praise for the film, Spivak discusses the figure of Rosie, "white, deliberately downwardly class-mobile, a social worker, heterosexual," as part of the general allegory the film dramatizes of "[a] critique of imperialism which in itself was very class marked." There is an important scene in the film in which Rosie confronts her lover's father, Rafi, over his record of human rights abuses, information that comes to Rosie by way of an organization we imagine to be something like Amnesty International. Rafi is a man who spent his youth in England fighting British imperialism and returned to his homeland to take up the cause of nationalism. We find him, at the moment of the film, coming back to England having gained wealth and political power through suppression, torture and a denial of human rights. In the following passage Spivak launches into a critical account of the scene that is remarkable for its representation of Rosie's radicalism in terms of three key topoi, (white) women, animals, and torture:

One of the most important moments in the film is when Rafi and Rosie are having their row in the restaurant. Rafi's line is that [Rosie] doesn't know what it is like in decolonized space and she's giving the line about there being no excuses for torture. They're screaming at each other and everybody in the restaurant forms a sort of audience so that it becomes a public performance. At a certain moment the camera holds on a close-up of Rosie so that it almost looks like a still. Rosie has those incredibly very sharp weapon-like earrings, and the profile is frozen in such a way that it looks as though a sort of caged beast has been cornered. And that to an extent is the beleaguered position of the civilized conscience for whom torture is bad under any circumstances. ... And the reason that one can't read Rosie is that she dramatises this confrontation between radicalism and an old fashioned simple morality based on rather simple ethics. (82)

In Spivak's account of the scene, Rosie embodies the traits of the tortured animal, caged and immobile; the very tortured victim that Rosie 
seeks to affirm in holding Rafi accountable for his actions. For Spivak, Rosie is an ambiguous figure: on the one hand she is politically "radical" and, yet, on the other, due to her ignorance of the history of British imperialism, left no other recourse than to resort to a "simple ethics" in order to clear a space for criticizing some of the tactics of nationalist struggles in the Third World. I do not think that Rosie is that hard to read or, in Spivak's terms, cannot be read, even given the ambiguousness of her position as a First World Woman confronting Third World Nationalism. She may be naive but she is also right. She may not fully understand that the individuals Rafi has tortured opposed his bourgeois nationalist claims to power but she is quite rightfully opposed to the use of torture. How else are we to understand Rafi's suicide at the end of the film if not as a tragic marker of the failure of nationalist struggles in the Third World following the Second World War to achieve truly independent, democratic societies?

In Spivak's reading, Rosie becomes the conventional misogynist trope, woman as a beast of stupidity. She is reduced by Rafi to the ultimate feminine victim, her victimage defined by her immobility as described by Spivak. Ironically, Spivak turns Rosie's political opposition to Rafi's use of torture against her; thus, turning Rosie into a further victim of Rafi's, and thereby profiting from his patriarchal condescension toward her. Another way to read this scene might be to situate Rosie in her political position as an agent of feminism, rather than as an undefined "radical," and address the contradictions of a new social movement such as feminism in its relationship to anti-imperialist and Third World nationalist struggles. In doing so we can shift the critical register from a question of "simple morality" to the problem of being represented as a single agent in a singular political struggle. To claim, as Spivak does, that Rosie is indulging in simple morality is precisely to play into the hands of those who would have criticism from the West discounted simply on the basis of its historical culpability. Such a politics of guilt leads to the silencing - a constitutive aspect of the immobility to act - of any oppositional voice, whether in England or in India, for example. In the context of acknowledging the uneven relations that exist in any political struggle, Rosie and Rafi can be seen to re-present highly politicized positionalities that come up against each other, because of imperialism, because of feminism. Such a disruptive encounter between anti-imperialist nationalism and British feminism should not surprise us. Rather it should re-awaken us to the continuing effects of imperial- 
ism - cultural, ideological, class-marked - and urge us on to unravel and denounce the oppressive and exploitative relations that exist between women and men, women and women, as those gender relations intersect with global economic and political forces.

The film Sammy and Rosie Get Laid, and my critique of Spivak's discussion of it, open up worlds of difference in how we can view the interconnectedness of gender, territorial expansion and the world's trade in commodities. The question of race contributes another dimension.

\section{Second Skin}

The AA subway train to Harlem. I clutch my mother's sleeve, her arms full of shopping bags, christmas-heavy. The wet smell of winter clothes, the train's lurching. My mother spots an almost seat, pushes my little snowsuited body down. On one side of me a man reading a paper. On the other a woman in a fur hat staring at me. Her mouth twitches as she stares and then her gaze drops down, pulling mine with it. Her leather-gloved hand plucks at the line where my new blue snowpants and sleek fur coat meet. She jerks her coat closer to her. I look. I do not see whatever terrible thing she is seeing on the seat between us - probably a roach. But she has communicated her horror to me. It must be something very bad from the way she's looking, so I pull my snowsuit closer to me away from it, too. When I look up the woman is still staring at me, her nose holes and eyes huge. And suddenly I realize there is nothing crawling up the seat between us; it is me she doesn't want her coat to touch. The fur brushes past my face as she stands with a shudder and holds on to a strap in the speeding train. Born and bred a New York City child, I quickly slide over to make room for my mother to sit down. No word has been spoken. I'm afraid to say anything to my mother because I don't know what I have done. I look at the sides of my snowpants, secretly. Is there something on them? Something's going on here I do not understand, but I will never forget it. Her eyes, the flared nostrils, the hate. - Audre Lorde, Sister Outsider

In the figure of the fur-clad woman, we find a monstrous combination of class privilege and racial hatred, in short, white, gendered supremacy. In Lorde's account of the woman in fur, what gives rise to the imaginary 
beast - the roach - that comes between herself and the woman is the imaginary line drawn between Lorde's and the white woman's bodies. What is at stake in Lorde's text is the proximity of theblack female child to the white adult woman. The fur coat provides the necessary barrier for the white woman to protect and guard her appearance of power through the status of fur as a sign of wealth. Fur provides the simulation of a skin that lacks pores through which oxygen and other elements could seep. It is like a shield of armour, impenetrable, unalterable, a self-preserving skin. 'Skin is not something you can change like your clothes.' But skin is not a prediscursive entity with pregiven meanings and values: its significations are constructed in the relative articulation of positions of power and control. This self-preserving skin that cannot change its colour figures as the immutable substance of social stasis. What Lorde's image of the fur coat dramatizes is the white woman's horror of contact: horror that is a fantasy of non-contact mimicking an absolute division of racial difference.

The fur coat has a dual function in Lorde's narrative. Not only does it signal an impenetrable barrier necessary to the codification of racial difference (in order to discriminate between black and white, the colours must be clearly delineated), the fur coat also works to alter the reception of human relations and to clothe those relations, as it were, in a coat of a different colour, that is, in the realm of animal relations, as an almost but not quite sign of humanity. No writer has explored as graphically as Franz Kafka in The Metamorphosis the strained and alienated indifference of human relations in terms of an abject animalization. Like the phantom roach that emerges in Lorde's account, Kafka's metamorphosis of human to animal, man to roach, succeeds because of the contempt, disgust and filth this creature epitomizes in our urban imaginations. The roach is that with which one does not want to have contact. Kafka's novella is particularly intriguing for its incorporation of an image of a fur-clad woman. She appears on the first page of the text in a photographic display on Gregor Samsa's wall: "Above the table on which a collection of cloth samples was unpacked and spread out - Samsa was a commercial traveller - hung the picture which he had recently cut out of an illustrated magazine and put into a pretty gilt frame. It showed a lady, with a fur cap on and a fur stole, sitting upright and holding out to the spectator a huge fur muff into which the whole of her forearm had vanished!" (7) After Freud's classic account of the fur fetish as "the sight of the pubic hair which ought to have revealed the longed-for penis," 
(201) such an image is overdetermined to the extent that its effect is comedic, an amplified version of 'castration anxiety' blown-up with the aid of photographic simulation: in Deleuze and Guattari's words, "An Exaggerated Oedipus."

In Kafka the relationship between the fur-clad figure and the roach are proportionally inverse to Lorde's characterization of the same. In Lorde's narrative the roach appears as a phantasmatic effect of the white, fur-clad woman's desire for power and supremacy (non-contact), in short racism, while in The Metamorphosis the fur-clad woman (especially in a later scene when Samsa/the roach hurls himself at the image) figures as the simulated phantasm of unrealized sexual desire. In both cases the fur-clad woman represents that which is untouchable. In both cases contact with the fur -clad woman is denied because of the filth associated with the roach. The inverted location of the phantasm in these respective texts (the roach appears for Lorde as a projection of the fur-clad woman's racism, Samsa-as-roach projects his castrated sexual desire onto the image of the fur-clad woman, thus turning the simulated image into a phantasm of sexual desire) signals a significant difference in how the respective relations of domination (racial/sexual) materialize in terms of 'race' and 'sex' differentials. This is where the central inversion occurs: between significance in material reality and the material signification in language. The phantasmatic effects produced upon the material realities of racial and sexual oppression allegorize the indispensability of 'race' and 'sex' differences to narratives of domination. Phantasmatic effects mark a failure to make fully present the realities of segregation (i.e. noncontact), and yet, as a phantasm, which here functions as a metaphor for absence, racial or sexualized differences obtain visibility (but not full presence) as that which is being made invisible. Lorde's narrative is especially compelling as the phantom roach makes visible the invisibility of the fur-clad woman's racism. The moment invisibility breaks open into a domain of visibility constitutes an inversion in the usual order of subordination. Furthermore, the relations of power on which that order of subordination sustains itself are displaced to the extent that a new order of hierarchical relations cannot possibly fully materialize. The fourth section of this essay, "Fourth World: Fantasies and Teachings in a Transnational Frame," will discuss the dangers of making fully present one object of racial oppression and how such a 'progressive' manoeuvre can reinstate the relations of domination. 


\section{Third Class}

The location, elsewhere, of a radical difference is the domain of theOther, a site on which the Subject consolidates its position. The Diesel jeans advertisement (see p. 62) makes no bones about where that Other is located, smack in the middle of the most highly profitable realm of ideological codification: the fashion apparatus. "How to control wild animals?" Domestication is the answer, a neolithic resolution to the problem of dealing with waste: "wasting space, wasting time, using the planet as a toilet!" The schizo-rhetoric of the advertisement flows from a suggestive association of the black woman/wild animal with all the baggage this eye-catching racial inscription of the untamed, uncivilized black woman carries, to an ironic displacement in the call to build zoos and metal cages for the production of a not "natural" beauty, all too reminiscent of caged animals in fur factories. She is both the sacrificial black sheep and the redemptive figure of irony, signalled no less by the cross hanging around her neck. The engineers of this image signal their position - in what is quickly becoming a popular quest for simulated politics - in a further appropriation of another redemptive figure: the Indian. The signature of the Mohawk brave is stamped above another logographeme: "Number 7, in a series of Diesel 'How To ...' Guides to SUCCESSFUL LIVING for PEOPLE interested in general HEALTH and mental POWER." The multiplicity of logos suggests a desire to cover all bases, to enter the fashion code into the discourse of politicality, because it is only in the realm of ideological codes that our liberty of choice lies. Nothing about this advertisement tells us, the spectator, about the exploitative conditions under which women labour in the textile industries of the Philippines, Mexico, and South Korea, even if we are talking about "workwear." In fact, one could almost be convinced by the rhetoric of political simulation that the domain of exploited labour has disappeared from the face of the earth and we are left only with an ideological mode of resistance illustrated in the advertisement by its call to "general HEALTH and mental POWER." At least this advertisement is clear about one thing: the inscription of racism, and, at the same time, a concern to add an ironic disclaimer, tell us that complicity is afoot. And its location is elsewhere: "Shopping malls, mega parking-lots, golf courses." Isn't that what First Nations' lands are for? Isn't that what the Third World is for? Isn't that what the wilderness is for? 

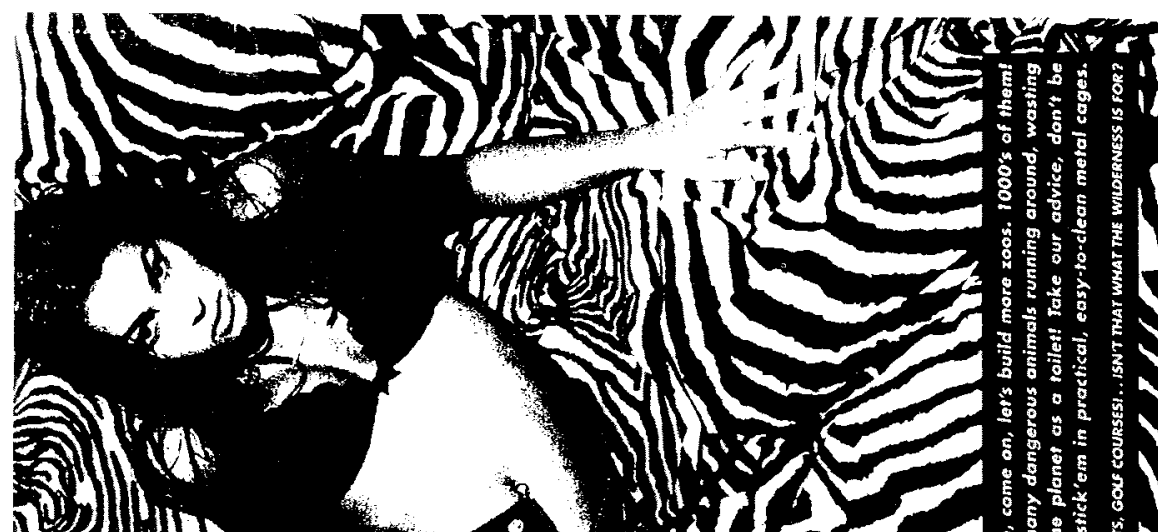

의
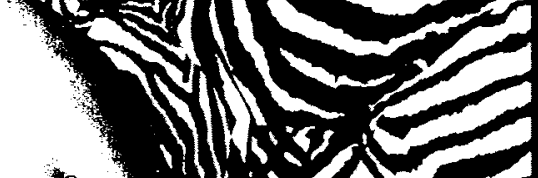

है

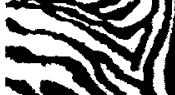

$1,1)+2$

D)
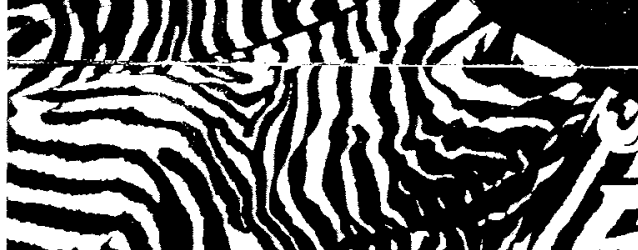

is:
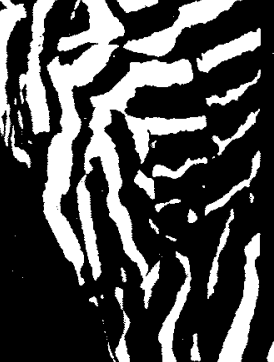

${ }_{-\infty}$ (x) H M 3 W

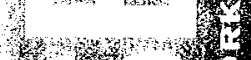

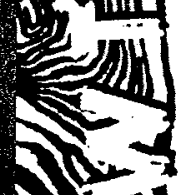

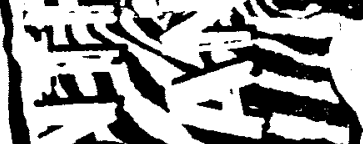
$1-11$

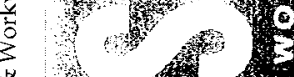

气

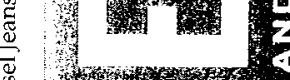

$\ddot{0}$

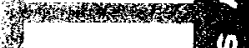

17.

3 \% 4

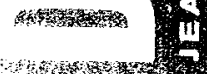

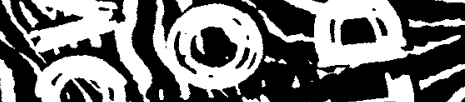

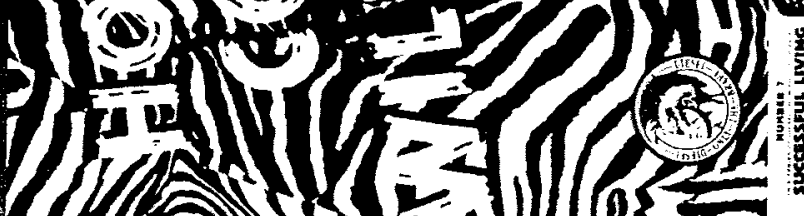

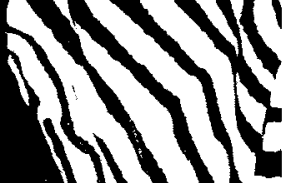




\section{Fourth World: Fantasies and Teachings in a Transnational Frame}

None of this, however, has had very much bearing upon intellectuals in the West for whom issues of tyranny, social justice, and the violation of human rights are supposedly central. What we should observe is how the Israeli practice of separation between Jew and non-Jew has been translated ideologically into something different from all other practices of discrimination, so that-as a case in point - comparisons between the Palestinians and American Indians or South African Blacks are routinely not made, even though similarities between them all are striking. - Edward Said, "An Ideology of Difference"

Identitarianism can be as dangerous as it is powerful, and the radical teacher in the university can hope to work, however indirectly, toward controlling the dangers by making them visible. - Gayatri Chakravorty Spivak, Outside in the Teaching Machine

Imagine you are an undergraduate student in a Political Science or Canadian History class and you are being asked to participate in a pedagogical exercise in the 'experience' of cultural imperialism. The intention of your instructor is to introduce you and your fellow students, a predominantly non-Native student group, to First Nations' experience of colonialism through an event designed to evoke a high degree of affect: a highly charged, emotional response to 'feeling oppressed.' Remember, this is a fantasy and yet, while the story is a simulation of a desire for undoing domination, its effects are very real.

The simulation, entitled "The Raven's Tale," begins with a post-apocalyptic scene. ${ }^{2}$ North America has been devastated by an atomic war and the population of Canada has been reduced to less than a quarter of a million people. The United States becomes Canada's self-appointed protectorate and assigns "the Arabian states" the task of re-building the country under the new name "New Arabia." To some of you, this exercise will already have struck a nerve. A fellow student mumbles something about Palestinians which strikes you as odd since how could a similarly disenfranchised transcolonial nation such as the Palestinians figure as imperialists in a simulation exercise that is about the experience of imperialism. You turn to your instructor who is qualifying the use of Arabia by saying that absolutely no disrespect is intended towards any 
real Arab cultures or customs. Their use is only as convenient metaphors. You agree to be patient. To fill out the scenario you are told that millions of people are moved to the new world of Arabia and that they bring with them their governmental, educational, and religious institutions as well as their language and customs. Those Canadians who survived the atomic war find it next to impossible to adapt to this new regime, largely due to the difference in languages. They discover that only jobs requiring physical labour are open to them. The government of New Arabia decides to portion off small areas of land held in reserve for the Canadians and to institute a "Department of Canadian Affairs" (DCA) to administer educational and social services.

The document provides you with a set of problems you must cope with under this new regime of power:

\section{First Problem}

Imagine you are leaders of a small group of 300 Canadians on a new reserve set near Prince George, BC. As leaders you are expected to solve any problems your people have in coming to terms with the new situation. Some of the problems you are faced with are:

1. You are forced to send the children to an Arabic school system near Victoria, BC. They will be gone ten months of the year. They will be learning Arabic customs, history, religion and language. They will not be allowed to speak any other language. Sometimes the children are kept even through the summer months, and end up staying away for 3-4 years.

2. The Arabic government, in order to act in your best interests, is encouraging Moslem Missionaries to live on your reserves. All Christian and other religions [sic] ceremonies are declared illegal as those beliefs encourage customs unacceptable to the new Moslem Nation. Church vestments and relics are burnt, or placed in museums.

3. All books, T.V. programs, radio programs, and movies are now only in Arabic. AllEnglish-speaking material was destroyed during the war.

4. Your system of justice is gone and has been replaced with an Arabic system. The new system includes stoning, beheading, firing squads and imprisonment. They are also very heavy on religious infractions. Your hand is chopped off for theft.

5. Everything you do that involves community improvement i.e. housing, employment, medical services, must be dome through the DCA (Dept. of Canadian Affairs) and they speak only Arabic. You are 
considered a ward of the government and can only leave the reserve with permission.

6. If any of your people wish to succeed off the reserve, they must first master the Arabic language, work, dress and social habits, plus facing [sic] varying degrees of discrimination and prejudice. Because of the language and cultural differences at present, all available work off the reserve is basically labour-type jobs, i.e. digging ditches, garbage collecting, dishwashing, etc.

7. The Arabian government feels that Canadians cannot handle liquor (Arabian religion frowns on drinking) so they have prohibited all drug and liquor use by Canadians, although hashish (and other marijuana related drugs) are legal and available to Arab citizens to this New Arab world.

8. Canadians are not allowed to vote in this new Arab Territory as the government feels that they are ignorant in Arab matters, and therefore cannot be responsible citizens. You are no longer able to elect your leaders in the democratic manner in which you were raised (secret vote, etc.). DCA now determines who will lead with the advice of the Moslem Missionary and DCA agent.

9. There are obvious differences of opinion among members of your community:

(a) Many are apathetic and don't care what happens. They have suffered too much heartache and sorrow as a result of the war.

(b) Some wish to link up with other communities and attempt to form a distinct and independent Canadian group within New Arabia.

(c) Some wish to re-unite all Canadians and reclaim their country.

(d) Some wish to become Arabian as rapidly as possible.

(e) Some wish to keep each community separate and distinct, isolating themselves from the New Arabian society.

\section{Directions:}

You are now a Council Member. Conduct a Council meeting to determine how your people will face these changes. Set some goals so that your community will have some direction for the future. Write out your answer to each situation, an answer agreed to by the majority of your group. Write out your responses on the large paper provided. Remember that you are a leader and people are looking to you for answers and direction. 
The point of this exercise is to conjure the necessary feelings of victimization and fear that have been the result of British and French imperial practices in Canada. The exercise also cleverly draws attention to the destructive effects of Canadian state policies since the late nineteenth century, such as those administered through the Indian Act (1876) regarding the residential school system. (This Act prohibited the speaking of aboriginal languages and the exercising of spiritual practices, created the reserve system, and later formed the Department of Indian and Northern Affairs.) These colonial policies plus the religious dominance of Christian missionaries within the residential schools and on reserves strategically appear in the exercise as characteristics of the new imperial culture (see problems 1,2,3,5). The reference to the problem of liquor consumption in problem 7 recalls the racist stereotyping of First Nations peoples as 'drunken injuns' propagated most forcefully by media and Hollywood movies. Problem 6 addresses the question of access to the professions by pointing out how such access is a matter of possessing cultural capital: the socially acceptable linguistic, behavioral and educational background.

Now the raven is a notorious trickster, so let's proceed with caution for the raven may have something more to teach us about the subtleties of colonial effects than this exercise may initially make apparent. One of those effects is racism. The logic of discrimination through which racism is permitted to evolve rationalizes the positing of a division between an 'us' and a 'them.' Constitutive to this process of differentiation is the formation of an impermeable borderline, a line that demarcates a categorical difference between oneself and an other (a line which we encountered in the shape of a fur coat in Lorde's narrative). The divisible relation between the one and its other functions on the basis of stratification. The logic is in fact endemic to the modes of stratification produced in trans-economic and trans-political force fields. In other words, the logic of racism is the logic of late-capital trans-nationalities. And while we may selectively become attuned to the intolerable divisions we live in, and resolve the habitual oppressions of (certain kinds of) sexism, such as heterosexism, and (certain kinds of) racism, such as that directed toward African Americans or First Nations people, these partial resolutions signal a larger problem. For the logic of racism can accommodate itself to any particular group even as it shifts progressively away from one group toward an other. The scapegoat figure is a necessary condition of the logic of late capital trans-nationality. Indeed, global expansion provides 
a multiplicity of possibilities for the mechanisms of differentiation to operate. Racism, then, represents a partial effect of colonization and as a partial effect mimics that partiality in its very logic of selection. There is a tremendous risk in reproducing the logics of racism when we critique colonization solely from a position of its partially oppressive effects. We risk setting the power of selectivity in motion and shifting the borderlines between one set of differences onto another. And this is where the value of this simulation exercise is to be found: in what it can teach us about the meaning of racism and how racism operates by selectively discriminating between an 'us' and a 'them.'

It may be argued that the reference to "New Arabia" amounts to nothing more than a convenient metaphor because to use a reference to aliens or some fantastical people would make the exercise too surreal for the participants to gain more than an intellectual understanding of the effects of being colonized. In other words, to illicit the (politically) correct emotional response, to conjure up the right feelings of anger, hatred, fear, victimization, etc., a real example was necessary. Even so, what we have here is not a real or true Orient (Islam, Arab, or whatever) but rather, as Said writes in Orientalism, a "constituted entity" (322). Why does this constituted entity, this representation of the Arab, conjure just the right constellation of feelings? Edward Said offers the following explanation:

In the films and television the Arab is associated either with lechery or bloodthirsty dishonesty. He appears as an oversexed degenerate, capable, it is true, of cleverly devious intrigues, but essentially sadistic, treacherous, low. Slave trader, camel driver, moneychanger, colourful scoundrel: these are some traditional Arab roles in the cinema. The Arab leader (of marauders, pirates, "native" insurgents) can often be seen snarling at the captured Western hero and the blond girl (both of them steeped in wholesomeness), "My men are going to kill you, but - they like to amuse themselves before." Heleers suggestively as he speaks: this is a current debasement of Valentino's Sheik. In newsreel or news-photos, the Arab is always shown in large numbers. No individuality, no personal characteristics or experiences. Most of the pictures represent mass rage and misery, or irrational (hence hopelessly eccentric) gestures. Lurking behind all of these images is the menace of jihad. Consequence: a fear that the Muslims (or Arabs) will take over the world. (286-87) 
Theproblems outlined in the exerciseneed furtherdiscussion based on Said's explanation. This constituted entity is constructed in problem 2, for example, when an image of "Moslem Missionaries" burning church vestments appearsinsucha way as toreinforcethecontinuoususeby film, media, and newsreel images of the dreaded "Islamic threat," that, as Said writes, dramatizes "the menace of jihad." Since we are dealing with a stereotypical reference that incorporates all Arab people into its domain, it is worth noting that the reference to "all Christian and other religions [sic] ceremonies are declared illegal" might strike-just as an example-a ChristianPalestinian Arabliving and practicingherorhis faithin thebirth place of Christianity as a somewhat puzzling suggestion.

Problem 7, with its reference to hashish, should also be noted even though it presents the most confusing of references. On the one hand, the reference to hashish exists only in order to provide a counter example to the prohibition against liquor, as well as introducing an element of hypocrisy into the new order of dominance; on the other hand, this counter example is suggestive in and of itself as it underscores typical Western perceptions of drug-consuming Mediterranean cultures. More than that, however, I would suggest the image recalls colonial (British and French) representations of Middle Easterns and North Africans as drug smugglers, marauders, raiders, etc. Neither references in problems 2 and 7 deal directly with the colonial experience of First Nations. With regard to problem 4, except for the reference to imprisonment which signifies the extraordinary over-representation of First Nations peoples within Canada's prisons compared to any other social group, the allusions to "stoning, beheading, firing squads" and "Your hand is chopped off for theft" bear absolutely no relation to Canada's colonial history. Rather, these images and those contained in problems 2 and 7 depict a barbaric, subhuman, sadistic group of people: the Arabs.

Used only as a convenient metaphor, Arab culture is constituted by its ready accessibility to the minds of students as a forceful example of a demonic 'other' which will surely succeed in creating the necessary terror the students are encouraged to feel in order to understand the horrors of imperial contact. Indeed, the success of this exercise depends precisely upon its ability to conjure the necessary feelings of victimization, fear, outrage, if not the call for armed insurrection: the popular culture and media depiction of the Arab is the perfect instrument.

Edward Said notes "how readily 'the Arab" seems to accommodate the transformations and reductions - all of a simply tendentious kind - 
into which he is continually being forced" (285). This mode of accommodation is indeed a convenient form of racism. One of the key operations of racism includes cultural stereotyping, the reduction of cultural diversity to a few particular features that take on the role of universally representing all individuals associated with the culture at large. Cultural stereotyping inevitably gives way to a process of homogenization, the lumping together of diverse cultural practices into one monolithic 'thing.' This homogeneous thing is then situated as a Big Other, radically different from one's own culture and, as such, incomprehensible and inaccessible. More than a Big Other, this homogeneous thing carries a negative value in order to uphold the positive value of the dominant society. These are the underlying assumptions necessary to create a hierarchical division between ' $u$ s' $^{\prime}$ and 'them.' A student participating in this exercise would, I think, be left with the impression that while the exercise simulates imperialism, the imperialists are real-world Arabs representing a culture that is nothing more than a homogeneous representation of 200 million people of diverse religious, cultural, political, social, economic and ethnic backgrounds. If our understanding of cultural difference is based on the difference between us and them and not on the basis of multiplicity or on the way that hierarchical differences are produced by political and economic forms of power that stratify our social relationships to each other, then we remain trapped within the logic of racism. If a student cannot distinguish between the British government's foreign policy and the people who may or may not have been opposed to its imperial practices, won't the same student be unable to distinguish between, for example, an authoritarian regime such as that in Saudi Arabia and its oppressed population, as well as the population of the remaining 21 Arab countries?

While supposedly experiencing the victimization of colonial oppression, an experience gained at the expense of racist stereotyping and demonizing of the Arab and Arab cultures, students do not engage in a process of critical thinking which would allow them to understand the meaning of racism in a broader context and to see its application to all forms of cultural stereotyping, homogenization and discrimination. It is not enough, in other words, to understand one culture's particular experience of racism without understanding the breadth of the scope and effects of racism in general. While this simulation exercise may teach students something about First Nations' experience of racism, they will fail to learn anything about the ideology of racism and the extent to 
which it can be put to use in dividing people from each other: in this case, what is elided is the comparison which is "routinely not made" between people whose respective struggles are, as Said notes, more historically comparable than is generally acknowledged.

In the original version of this exercise the following remarks are appended to the text:

Please note that this exercise is designed to demonstrate the effects of colonialism on aboriginal culture in Canada by European cultures, and it uses an exaggerated version of "Arabian" Culture to help people to see past the familiarity of their own cultural bias. This is explained at the end of the exercise, and helps to show the participants, in turn, how readily we accept stereotypes about other cultures as well. This is part of a course on understanding bigotry and prejudice based on ethnocentric views of other cultures.

This closing caveat was excluded from the adaptation. One of the consequences of this exclusion is to throw the meaning of the exercise into question: does such an exercise teach a non-native student about the effects of colonialism on aboriginal culture? Or does it teach them about the effects of colonialism in producing a system of differentiation that separates 'us' from 'them,' while encouraging a selective consciousness about who occupies the subject position ('us') and the position of other ('them'). For selective consciousness about racism is acceptable and, yet, such discrimination between those one can't be prejudiced towards and those one can, should tell us that the fundamental lessons of racism have not been learnt; indeed, in this exercise, racism has been reinforced. It is only from a transglobal perspective that the equally disturbing racism toward Arab people becomes apparent.

The danger here is the setting up of a competitive relationship between identifiable political groups. The competitiveness of political difference elides the difference between dominant and underclass forms of racism. Gayatri Chakravorty Spivak, in Outside in the Teaching Machine, gives us the following example:

In Britain in July of 1988 a section of underclass "Asians" was vigorously demanding to be recognized as different from underclass "Blacks," basically because they felt, by the deplorable logic of underclass racism, fed by poverty and encouraged by the ruling 
class, that on account of their cultural attributes of mildness, thrift, domesticity, and industriousness, they were, unlike the lazy and violent peoples of African origin, responsible and potentially upwardly mobile material. (54)

Negotiating her own experience of underclass racism, Barbara Cameron, a Native American, writes the following:

Racism is not easy for me to write about because of my own racism toward other people of color, and because of a complex set of "racisms" within the Indian community. ...I've grown up with misconceptions about Blacks, Chicanos, and Asians. I'm still in the process of trying to eliminate my racist pictures of other people of colour.... Racism among third world people is an area that needs to be discussed and dealt with honestly. We form alliances loosely based on the fact that we have a common oppressor, yet we do not have a commitment to talk about our own fears and misconceptions about each other. (49)

Spivak gives us a poignant analysis of the potentially unperceived role the academic may play in attempting to administer these complex levels of racial negotiations:

Distinguishing between Africa and Asia in terms of kinship to Europe is an old story. As a politically correct Asian, of course, I find this story deplorable. Yet it can be said that first, a well-placed Asian academic can afford to find it deplorable; and, secondly, that academic insistence on a politics of difference may be equally as competitive in intent. To a London audience, academics and cultural workers, eager to hear a speech on cultural value, it is important that the speaker's identity that afternoon was "Asian," with underclass differentiations out of sight. Unless we continue to nurse the platitudinous conviction that the masses are necessarily identical with "the revolutionary vanguard," or conversely that, stepping into the university, "The truth has made us free," we must attend to the possibility of such dissension, and their imbrication with the history and burden of names. (54)

Spivak, along with Audre Lorde, works to make visible that which has hitherto been made invisible. As this simulation exercise illustrates making visible can be as much an indirect as a direct effect of attending 
to the identity politics of current new social movements. The dangerous side of identitarianism is to be found in the tendency to enforce competitiveness among politically identifiable movements when a politics of difference is introduced in order to give a proper name to the place of 'marginality' (read as revolutionary vanguard). And the name for marginality can change as often as the wind blows. In turn, the academic centre (where "the truth has made us free") retains its position as the site which manages marginality and the marginality of group identities, all the while giving off an aura of progessive critical engagement. Marginality here becomes a metaphor for the confusion between the desire for a fully present Other, with which one hopes impossibly to have contact, and the similarly impossible desire to undo the border between the self and the other through a process of political simulations. At best, I think we can follow the lead of Lorde and Spivak by attempting to make visible the invisibility of politically inscribed differences.

\section{In the last instance: Significations in Motion}

In the final instance the fantasies of (non-)contact do not differ from the realities of (non-)contact: both are circumscribed by significations that extend beyond the immediate resolutions to contradictions and tensions in material existence. Those resolutions can only ever be partial or provisional to the degree that existence itself has become a selective process of sorting events, moments, images, powers and knowledges. The movement of peoples across the globe, the diasporic shifts produced by imperialism and maintained by the flows of transcapital circuits of exchange, demands an equally mobile, provisional and partial process of reading. A transactional reading tracks the mobility of partial meanings and provisional values across the sites of differentiation produced in time and in space. Currently those sites of differentiation are constituted by questions of gender, race, sexuality, nationalism, and class. These questions are not the only ones to be asked but the struggles of women, the working class, lesbians and gays, First Nations, African Americans, Palestinians, etc., would certainly suggest their historical urgency, if nothing else. These questions can be mobilized in such a way as to remap our critical orientations in a transnational frame where the history of territorial expansion and the flows of capital determine the parameters of the 'big picture.' In this picture, not only might those transnational complicities Spivak mentions in the epigraph to this paper be perceived, 
but also, and more importantly, the interests that underlie our not perceiving them become speakable, visible, and intelligible.

Many thanks to Elie Korkmaz for his critical comments on the paper in general, and specifically for his crucial input into the discussion of the simulation exercise. Thanks are also due to Jennifer Henderson for her editorial comments on an earlier draft of the paper.

\section{Notes}

1 It is somewhat of a telling paradox that the economic activity of fur-trapping encouraged by British mercantile expansion and later colonialism with its enormous effects on First Nation's economic survival and political autonomy, should, after a few hundred years, become subject to an ecological critique, that in itself, is, once again, threatening the self-governance of First Nations. See my "Simulated Politics: Animal Bodies, Fur-Bearing Women, and Indigenous Survival," forthcoming in 24 New Formations (Winter 1994) for an extended discussion of this problematic.

2 "A Raven's Tale" is an adaptation of an exercise originally developed by Lee Oates, a registered psychologist with the Terrace Mental Health Centre. The exercise bears no copyright and is generously given to anyone who would like to use it for pedagogical purposes. Many thanks to Lee for allowing me to discuss this exercise, and to put the exercise to work in a context for which it was, perhaps, not intended. There are some important differences between the original exercise and the adapted version, not least of which are the closing remarks to be found in Oates's version (which were excluded from the adaptation) and to which I will return in the text. My analysis of "The Raven's Tale" depends entirely upon this "exclusion." I should also note here that this adapted version fell into my hands by accident, its origins difficult to trace.

\section{Works Cited}

Cameron, Barbara. "Gee, You Don't Seem Like An Indian From the Reservation Deleuze." In This Bridge Called My Back: Writings by Radical Women of Color. Eds. Cherrie Moraga and Gloria Anzaldua. New York: Kitchen Table: Women of Color Press, 1981, 1983. 46-52.

Deleuze, Gilles and Felix Guattari. Kafka: Toward a Minor Literature. Trans. Dana Polan. Minneapolis: University of Minnesota Press, 1986. 
Emberley, Julia. "Simulated Politics: Animal Bodies, Fur-Bearing Women, and Indigenous Survival." Forthcoming in New Formations 24 (Winter 1994).

Flaubert, Gustave. Bouvard and Pecuchet with The Dictionary of Received Ideas. Trans. A. J. Krailsheimer. New York: Penguin Books, 1976. Freud, Sigmund. "Fetishism" (1927). In The Standard Edition of the Complete Psychological Works of Sigmund Freud. Vol 21. Trans. James Strachey et al. London: Hogarth Press, 1935-74.

Kafka, Franz. The Metamorphosis/Die Verwandlung. Trans. Willa and Edwin Muir. New York: Schocken Books, 1935, 1968.

Kureishi, Hanif, Sammy and Rosie Get Laid: The Screenplay and the Screenwriter's Diary. Markham, Ontario: Penguin Books, 1988. Landry, Donna and Gerald MacLean. Materialist Feminisms. Oxford: Blackwell Publishers, 1993.

Lorde, Audre. Sister Outsider. Freedom, CA.: The Crossing Press Feminist Series, 1984.

Said, Edward. Orientalism. New York: Vintage Books, 1979.

Said, Edward. "An Ideology of Difference." In "Race," Writing, and Difference. Ed. Henry Louis Gates, Jr. Chicago: U of Chicago P, 1985. 38-58.

Spivak, Gayatri Chakravorty. Outside in the Teaching Machine. New York: Routledge, 1993.

Spivak, Gayatri Chakravorty. "In Praise of Sammy and Rosie Get Laid." Critical Quarterly 31:2 (1989): 80-88. Republished with significant revisions as "Sammy and Rosie Get Laid" in Outside in the Teaching Machine, 243-254. 